\title{
RESISTANCE TO IDEOLOGY, SUBJUGATION TO LANGUAGE: A WORKSHOP BY WRITER GABIT MUSREPOV UNDER SOVIET TOTALITARIAN CENSORSHIP IN 1928-1964
}

\author{
Zhanat Kundakbayeva, Kamshat Rustem
}

\begin{abstract}
This paper examines how, under the control of strong censorship, some of Gabit Musrepov's literary works were published despite their seditious nature. The authors argue that although G. Musrepov was a reputable Soviet writer, the materials presented in the article prove that he worked at the meeting point of resistance and subjugation: resistance to ideology, subjugation to language. The literary analysis of Musrepov's three short stories shows that under the strictest control and actively expressed interest of the authorities in the writer's creative activities, the latter's mastery and the incompetence of censors allowed him to avoid the prohibition of his works.
\end{abstract}

Keywords: Aesopian language, allegory and grotesque description, censorship, hidden intonation of disappointment in the narration, mastery, national contextuality

\section{INTRODUCTION}

In the 1920s, Soviet political censorship was set up as a means of controlling people and society in general. As part of this Glavlit, a centralised censorship body, was set up. The structure of local censorship bodies copied Glavlit at the republican, oblast, and krai levels. Soviet political censorship increased in scale and refinement and operated in a secretive and conspiratorial way. Arlen Blum has noted: "No printed matter having any verbal meaning could appear without the permit of the Glavlit bodies - up to postcards, visiting cards, matchbox stickers, and invitation cards". ${ }^{1}$ The censorship system, which aimed to establish control over all forms of intellectual self-expression (including public speeches), proved to be so effective that it existed without cardinal changes until the collapse of the USSR. However, close reading of some works of the founder of the Kazakh national literature, Gabit Makhmudovich Musrepov (1902-1985), reveals that, although they were written during the Stalinist period and during the Khrushchev thaw, they overstepped the limits of the socialist system. 
What helped the writer to get around the impediments of censorship and avoid punishment? ${ }^{2}$

The article argues that, although Musrepov was a reputable Soviet writer, and the materials presented in the article prove this, he worked at the meeting point of resistance and subjugation: resistance to ideology, subjugation to language.

Musrepov lived in the most arduous and contradictory period in the history of Kazakhstan. He was deeply worried about the fate of the Kazakh peoples at a time when the only demand was to obey. Musrepov mirrored a discrepant and complicated epoch in the stories Glow (Shughyla, 1933), Why Are the Backs of Their Heads Itching? (Zhelkeler nege qyshidy, 1944), An Ethnographic Tale (Etnografiialyk änggime, 1956), and others. Under the strictest control and active interest of the authorities in the writer's creative activities, the latter's mastery and the incompetence of the censors allowed him to avoid the fate of having his works prohibited.

Musrepov's aesthetic experience proves that even in the most regime-engaged works (Kazakh Soldier, The Image That I Failed to Meet, In the Captivity of the Enemy) the writer was able to remain conventional. In connection with this, we should interpret in a special way one of his philosophical sketches, The Secret of the Work, included in the writer's Diary. His emphasised amplification of the meaning, given as 'astary' (a subtext, or having hidden motifs or implications) lets us conceive it not as an artistic method but as a worldview, a conceptual approach. Thus, in the writer's vision, a work is not merely content and form. A work has hidden motifs, indirect speech, comparisons. Musrepov (1997: 167) wrote that a hidden motif speaks indirectly through colours, songs, pictures, sounds, and whispers.

The writer's concentration on the moral problems of literature, the style of his works, remarkable for refinement, accurately adjusted, getting deep inside the consciousness, thoughts, and feelings of the reader, at the same time misled the censors and eventually resulted in the publication of his works. The intricate word of Gabit Musrepov indirectly and subversively stimulates a desire to dive into the text, invoking an anxious attitude to the text that envisages an opportunity of perpetual dialogue with the author, as the text is much more interesting than our fantasies, and correct interpretation in fact is an ethical behaviour before the Author. Musrepov often addresses his 'friend-reader', considering that such a co-authorship would provoke allusions and parallels that correspond to Soviet realities. 


\section{GABIT MUSREPOV - AN HONEST VIVID PERSONALITY}

During the Soviet period, Musrepov was recognised as the founder of the Kazakh literature. For services to the Soviet power he was given state rewards and the most generous premiums; he also earned the highest titles in the country. ${ }^{3}$ However, a close analysis of his literary works today lets us argue that he worked at the meeting point of resistance and subjugation: resistance to ideology, subjugation to language. His masterly language competence let him remain a deeply honest, decent person. Musrepov belongs to the short list of the Soviet intelligentsia that escaped reprisals but saved face even under the terror of the Stalinist regime.

Musrepov's formation as a writer took place in the years of the Stalinist terror. At that time he held responsible positions and was at the edge of ideological work. ${ }^{4}$ However, between 1938 and 1955, his rapidly developing career was interrupted for almost twenty years.

Gabit Musrepov was one of the first to talk about extremes during the collectivisation of agriculture in Kazakhstan in the early 1930s. For the well known Letter of the Five (1932) about the "leftist Goloschekin's methods of collectivisation", which resulted in famine and a high mortality rate among hundreds of thousands of rural inhabitants, and the words to defend B. Mailin (If Beimbet is the enemy of the people, I am enemy too), which he voiced at a party meeting in 1937, G. Musrepov was expelled from the party in 1938. Thus, the 18-year period of so-called 'freelance creative work' appeared in his working biography. ${ }^{5}$

What was he persecuted for? And, at the same time, how could he escape the fate of other representatives of the Kazakh intelligentsia? It was the time when during the first wave of terror the elite of the nation was repressed - people like A. Baitursynov, A. Bokeikhanov, M. Dulatov, M. Zhumabayev, Z. Aimautov and clouds were blackening over S. Seifullin, I. Jansygyrov, B. Mailin, and G. Musrepov. These people became a school of high intellectual honesty, moral responsibility, and civic courage. During the Stalinist terror, Musrepov became "an enlightened example"6 for his people. A contemporary patriarch of the Kazakh literature, Gerold Belger", has called Gabit Musrepov an "honest vivid personality": "In everyday life I remembered him as a person of principle who could openly and precisely voice his opinion to the public and did not conform to the life course to sweeten the authorities and the environment" (Belger 2002).

Thus, Musrepov's protest in the famous Letter of the Five to Stalin in 1932 became an act of reckless courage. In July 1932, the first secretary of the Kazakh krai committee of the Communist Party, F. Goloschekin, was addressed by writer Gabit Musrepov, head of the Kazakh State Publishing House Mansur Gataulin, vice rector of the Communist Institute Mutash Davletgaliev, vice rec- 
tor of academic affairs of the same institution Embergen Alatynbekov, and head of the energy sector of the state plan of the Kazakh ASSR Kadyr Kuanyshev. Based on the materials of the party fora and works of Stalin, they formulated a number of questions to which they responded themselves. The result of their considerations was summarised as follows: catastrophe in Kazakh agriculture, consequences of the leftist extremes in the politics of the Kazkraikom (krai committee) of the Communist Party and party organs in localities. All the authors of the letter were members of the communist party, and their memories perpetuated debates around the viewpoints of S. Sadvokasov, S. Khodzhanov, T. Ryskylov, and others on some aspects of the socio-economic development of Kazakhstan and maintenance of the national traditions of the Kazakh people. Keeping that in mind, the letter was accompanied by a short explanatory note:

The bearers of these issues are in no way 'offended' persons or persons seeking career [---] The only objective is to help the socialist transformation in Kazakhstan by pointing to some serious gaps, raising the troublesome issues in the Bolshevik manner straightforwardly before the krai committee within the framework of party democracy and in terms of self-criticism, which has been the chief weapon of our party. Therefore we are confident that you will respond to our questions, taking them as suggestions coming from healthy comrades of the medium level party officials, not influenced by any names of 'big' persons. (Gribanova 2003)

During the years of the Great Terror (1937-1938), Musrepov desperately defended his friend, another classic of Kazakh literature, Beimbet Mailin. Musrepov made an impressive statement at the party meeting dedicated to denouncing the counter-revolutionary activities of Mailin: "With such an approach I am people's enemy like him" (Shimyrbaeva 2002). Despite desperate efforts to defend his friend, ${ }^{8}$ Musrepov could not save him from arbitrary denunciation. Mailin was arrested on October 6, 1937, and on February 26, 1938, was executed on a falsified charge of being a people's enemy, a counter-revolutionary bourgeois, a nationalist rebellious terrorist, and a subversive, a member of a traitorous organisation aimed to overthrow the Soviet regime in a violent way (Beiskulov 2008: 227).

Musrepov was punished for his intercession and in 1937 he was expelled from the party and dismissed from his position of the head of the Culture Department of the Central Committee of the Communist Party of Kazakhstan. He was saved from imminent arrest by Alexander Fadeev, who arranged a secrete departure from Kazakhstan and safety for a year in Moscow (Shimyrbaeva 2002). Musrepov escaped reprisals, but for a long time disappeared from public life and lost his positions and status. For eighteen years Musrepov 
was jobless, but did not betray his principles. The writer lived on royalties on his works. During this period he made translations, working on the texts of Henry, Shakespeare, Moliere, Gorky, Sholokhov, Ostrovsky, and Simonov. He prepared for the stage Shakespeare's tragedy Anthony and Cleopatra, as well as some comedies, such as Niggard by Moliere and Talents and Admirers by Ostrovsky. That was a great school of craftsmanship. His civic position, courage, and decency, as well as his multifaceted literary talent allowed Musrepov to rise above others of the epoch. This is the reason why Musrepov is viewed in Kazakhstan not as a writer of a certain epoch but as someone above time frame (Bakhtin 1986: 353).

\section{AN ETHNOGRAPHIC TALE: WHAT DID THE CENSORS MISREAD?}

The Anthology of Modern Kazakh Literature published by Columbia University (USA) begins with an ethnographic story by G. Musrepov (2013). The story has an ironic undertone as if the author makes fun of the collectivisation drama. In 1956, as well as many years later, the writer was forced to make concessions to ideological censorship when touching on the hot topic of the establishing of kolkhozes in Kazakhstan. The compromises meant some revision in the original build-up of the story. Their real intonation was expressed by details of the kinetic language - gestures, mimics, posture, and reactions to the on-going process of social transformations of two young companions of Borovsky, a student from forestry technical school (Musrepov 1980: 296).

The author/narrator gives an ironic and discrediting evaluation of the imaginary scenes that were exposed in the new social conditions, i.e. opposition to the ideology and objectives proclaimed by communists. Existential disposition, obviously, is born in the moments of historical cataclysms that blow up the very fundamentals of established human existence.

The characteristic peculiarity of the rhythmical structure of the text in the original version of the Ethnographic Tale is in the creation of a moment of simultaneity of experience and the clarity of the visible image. This is shown by the acute and detailed elaboration of impressions of real, existing reality, given in the sketches of the big black yurt of Yesengeldy, its interior decoration redolent of former wealth and present day poverty.

Obviously, out of all yurts that I saw, it would undoubtedly rank first by the number of holes and slits. I have never seen them in such number and size even in the torn-apart yurts of the shepherds. Any shepherd's wife 
would mend even bigger holes. Five or six bore the traces of old colours and ornaments. The rest of the sticks resting on shanyrak [the upper dome-like portion of a yurt] seemed to be collected from the world around one by one - some were thin, others without curves, the rest could not even bear their names. Some five or six sticks had lost their colours, and were lamp-black. (Musrepov 1980a: 291)

The author's remarks, with their intonational/semantic validation, do not relieve the overall depressive impression from the detailed reconstruction of the ambiguous character. The functional role of the description of the yurt in the composition does not cause any doubts. The yurt, in such a miserable condition, shows the extreme impoverishment of its owners. In this sense, Musrepov's image has an association with Gogol's Dead Souls, where the house as a dwelling place in figurative poetics serves as an efficient means for characterising someone. Here we see also an exact parallel: the abject desolation of the mansion of the landlord Plushkin. In both cases social and psychological aspects of the allegoric mode correlate. The reason for pathological avarice in Gogol's plot and the depressive helplessness, maladjustment to life in Musrepov's text, indicated a caste belonging of personages: landlord and tore (aristocrats). Therefore, the contours of a social group's worldview are present as a subtext.

However, the historical perspective of Musrepov's narration also reflects a certain layer of national consciousness that had not yet dissolved into the turmoil of changing times and was not erased from the memory of the people. Kazakh national memory was bred on solid links between traditional customs and ritual, and therefore the story presents a conflict between traditional elders in the Zhanbyrshy aul (a village in Central Asia) and young visitors, Musrepov's companions, who openly ignore traditional customs. The source of the ironic attitude of the newcomers, without any doubt, is their young age, and they grow bolder under the impact of decisive, ruthless revolutionary eradication of the patriarchal fundamentals of the national way of life. But their boldness has limits too. The author-narrator and his young companions react to disparity between the traditional etiquette and the environment where that etiquette is played out with discontent. Nevertheless, they keep their emotions to themselves and "laughed inside themselves, and followed the rule of the game" (Musrepov 1980a: 291). The framework to study this game as part of culture was created by philosopher I. Heizing, who considers game and competition to be elements of a culture formation, which can be found in the interaction of groups (Huizinga 1992: 62). Musrepov's young companions understand communication as a form of game. He adds Kazakh ethnic colour to the figurative game. In the first translated edition, the reader notices a certain correlation between internal disagreement and the external restraint of the young actors: 
We got in. In that way experienced diplomats receive a delegation from an unfriendly country. Laughing to ourselves, we obediently followed that comical ceremonial.

He left. We again burst into laughter. (Musrepov 1962: 75-76)

In the second translation the hypertrophied laugh of the guests receives more space.

And we three, unable to stop laughing, were rolling around the floor with bulging eyes, clutching our mouths, with tearing eyes, belly muscles aching, and we could not stop. (Musrepov 1982: 494)

Detailed interpretation of the original text of the Ethnographic Tale lets us capture a hidden feeling of disappointment, regret, and sorrow in the narration contrary to emphasis on the "happy class" that appears in the Bulgarian interpretation (Musrepov 1977). This disappointment emerges as a result of the dissonance between the beauty of the world and the poverty of human life (Musrepov 1980b: 288):

The road that hadn't been used much led through the thick plants. After a hot day their shadow pleasingly cooled the face. Far ahead groves were appearing as blue semicircles, guarding the entire tract from the dry winds. Lakes kept appearing along the way and the wind blowing on my back kept quieting down in a continuous wall of cane. It seemed as if this little corner was purposely created to emphasise once more the soleness, the beauty, and expanse of our steppes [---] Soon a spacious ravine showed. Approximately ten dozens of yurts looked black in exuberant greenery. Horses walking without a leash started to come across, cows grazed by two, by three, sheep and goats wandered in packs. The first thing that struck the eye,

- How emaciated they were! Like some living skeletons just covered with skin. (Musrepov 1982: 489-490)

It is doubtful that even this exposition of the 'big picture of destruction' gives grounds for unbridled joy. All the more so because, in further text, the writer depicts convincingly the detailed process of dying, in which the yurts, like living organisms, are also symbolically the cornerstone of the Kazakh mode of life. The extraordinary behaviour of Musrepov's heroes, violating most rules of Kazakh education, only emphasises the dramatic situation - the living proof of "living in deconstruction" - showing how young minds misunderstood the fundamentals of the traditional culture.

These episodes raise the necessity to stress the problem of different levels of narration of the author-narrator and the hero. The personality of the author 
does not equal the personality of the hero. Moreover, the image of the authornarrator is different from the position of Musrepov as a writer. These contradictions occur in the mind of the reader of the Ethnographic Tale. The sub-text of the story becomes more understandable in the light of the controversy with the time of writing the story. In comparison to the officially approved publication date, the year 1956, there is proof that the story was submitted to a publisher in Moscow in 1942 (Musrepov 1982: 502). It seems that under the pressure of censorship the authorised translation was accepted only in 1956 . However, if we take the year 1942 as the true date, then the subtext contains even deeper philosophical and ideological aspects. The year 1942 was the hardest year of the Second World War when the scale of victims and suffering could have obviously contributed to the emergence of apocalyptic motives in the writer's work. The image of the aul cemetery symbolised not only the doom of Kazakh aristocracy (tore) but also the irreversibility of the tragedy that was experienced during the war.

If we take the year 1942 as an initial date for the completion of the Ethnographic Tale then another essay titled Why Are the Backs of Their Heads Itching? from 1944 should be linked to the first story. Both pieces demonstrate, on the one side, obvious resemblance to some thematic material and, on the other side, its interpretation. In both cases the description of a yurt is in the centre of the composition. G. Musrepov does not limit himself to one or two expressive details. His careful attention to detail carries an important task in forming the general concept. The extremely compressed story contains issues important for Musrepov, such as philosophical, social, and moral problems. The yurt as a semiotic concept is in the centre of the text structure, where shifted meanings of everyday objects and practices create the image of shifted, unnatural living conditions and way of life.

However, the context of the subject in its historical and creative aspects goes beyond these characteristics. In the Ethnographic Tale the kolkhoz theme is a framework for the development of the plot. At the same time the story line is almost lacking. None of the characters, visitors, or local people who live in the aul, tend to 'mark' the starting point in the historical prerequisites of the plot. This is surprisingly similar to the situation in Ivan Bunin's Antonovka Apples (Antonovskie iabloki, 1900), a story which matches with Musrepov's conception of re-construction of historical events. The narrator of the Antonovka Apples is deeply impressed by the destruction of the thousand-year state. There is a rapid change from 'previous' to 'current' reality. The story line has no breaking events, and the depicted situation is a reason for a nervous shock as well as for inner enrichment. The beginning part of the story structure has something in common with the ending part, to a greater or lesser degree. 
In the first sentences of the Ethnographic Tale the secretary of a district committee of the communist party calls the narrator for an action. In the end, the same district committee secretary is lost in thought and does not agree with the hasty conclusion of the narrator about the dawn of a new era. G. Musrepov implements the classical version of a circular plot structure, which means that characters acquire experience and change their worldviews while 'moving' along the circled structure of the plot. The mood of story-telling changes throughout the plot. In this particular case the change is very significant: from a derisive, ironic attitude to situations of life at the beginning of the story to a philosophical worldview and generalisations at the end of the story. Such contexture and story development is more inherent in an essay. This text passage is organised in order to question the ideology of positive changes under communism. Centripetal action exposes an obvious, clear idea as the story unravels and comes to the end.

As mentioned above, Musrepov very finely uses the genre diffusion of an essay and a story, an essay and a tale, and a story and a tale. A trigger for a process of thought in the plot is the author's statement: "We were running away from the aul, which was turned into a grave". The semantic meaning of the buried aul is widely exposed in the Ethnographic Tale, but the etymology is minimised. However, the meaning of the expression 'buried aul' appears in the text in a wide structural range.

First of all, a poetic element appears in the story's title - the gradual interrelation between the text and events as a reflection of one epoch, which, according to J. Derrida's pattern could be presented as an epoch of "being in deconstruction" (Derrida 1985). Ethnography, which by its meaning symbolises the existence of material and intellectual culture, is in this case turned inside out and shows the reversed meaning of what once was a system of values of life for people: abandoned yurts, social etiquette that has become irrelevant, and disintegration of social norms that regulated relationships between people of different ages.

\section{GLOW}

\section{BUILDING A KOLKHOZ IN KAZAKHSTAN:} A GROTESQUE IMAGE

Emphases on dramatic details in G. Musrepov's works form tragic accents that create a wider cultural framework. The motif of dramatic accents is combined with actual historic material in his story Glow, which dispels the myth of a bright future. On the one hand, Musrepov was deeply sensitive to the troubles 
and suffering of his people, and, on the other hand, he was very attentive to the word and its semantics. Glow shows violent formation of socialism in the USSR. In spite of allegory and grotesque descriptions, the story reflects numerous elements of real life under Stalin. The failed kolkhoz is a convincing example of the fact that people must not be forced to form a kolkhoz. This story reflects the traumatic experience of the author who witnessed forced collectivisation, which later resulted in the Great Famine of 1932-1933.

In the dialogues, which also include philosophical passages on the Kazakh worldview, the image of a town appears to be as senseless as its name (Musrepov 1980a: 113). Artificially constructed, denying the mentality of a traditional culture, the soulless phantom town represents the tragic historical conditions of forced collectivisation. In the wider context of world literature this image of a phantom town resembles the metaphor of the foundation pit (or kotlovan) used by Andrei Platonov in his works. ${ }^{9}$

In this story, a masterpiece of artistic representation, people who left their homes and were expelled from native auls, were more or less able to leave the 'ditch town' created by Musrepov (1980a: 114). In the story, people who did not accept the kolkhoz as a highway to socialism escaped one night. However, similar things did not happen that easily in reality. The transfer from real history to contextual space is shown in the tone of the metaphorical image of the title-Shughyla (glow, light, shine). The writer is absolutely familiar with the circumstances; he knows the living conditions of Soviet society, notices the halftones of the picture. In a few remarks (Musrepov 1980a: 104-105) he is able to depict the existing reality without any worldview or ideology. The abstract, a soulless pattern of ideology (Shughyla, a popular kolkhoz name in the 1930s) contradicts the reality of everyday life - the warmth, the smoke of the fireplace (tytini).

The scene of the suffering cow left in the steppe in winter makes a great impression on the reader (Musrepov 1980a: 105). The owner of the cow was accused of being a kulak (rich exploiter); his property was expropriated and he was sent to an unknown destination, most likely to Siberia. Everybody is guilty of this inhumanity - those who dispossess and those who are dispossessed. Collectivised and uncared-for cattle are an extreme symbol of inhumanity in kolkhoz organisation. In order to create a complete picture of a shifted, doomed way of life, the author uses visual evidence of physical emptiness, depopulation in Alyp (giant) kolkhoz. This picture shows not only a doomed idea, but also doomed people within the system. It is similar to the idea of tore (Kazakh privileged caste) family degeneration if there is no boy child among the children (Musrepov 1980a: 268). 
The story of the creation of Glow delivers an additional meaning to the essay. Musrepov's explanations, published in 1980 in his three-volume Selected Works (Tangdamaly shygharmalar) are given in a reserved form:

I decided to publish it again, even if 42 years has passed. The idea and content have not changed. It was an answer to critics' remarks. As a matter of fact, Shughyla has faced considerable misunderstanding and sharp hostility since it was published. (Musrepov 1980a: 116).

Gafu Kaiyrbekov's book Eltinzhal, published in 1990, contains invaluable evidence of late, tardy 'rehabilitation' of Glow. This was expressed in his diary:

He [Musrepov] was blamed by critics and went through periods of persecution. It was astonishing to see that even though he knew that this would lead to trouble, he took the risk and expressed his views and judgments in his writings; moreover, he published his works. To write this truth under threat of death was an act of a brave citizen, but understanding the writer's obligation to write the truth is twice a heroic act. (Kaiyrbekov 1990: 216)

Gafu Kaiyrbekov's thoughts are valuable as a source of historical facts that help to understand Musrepov's works and emphasise the outstanding character of the author: acumen, astute long sight, the writer's act of bravery and heroism are revealed in the stories Glow and Why Are the Backs of Their Heads Itching? (ibid.). Gabit Musrepov gave Gafu Kaiyrbekov a key to his Glow story: "Everything related to this tragedy is described in Glow, the memory keeps many facts" (ibid.: 205). After that G. Kaiyrbekov writes about Musrepov's remembrances:

A lot of white yurts. Seized property of the bai people [rich people]. It is difficult to imagine that a month or two ago there was a town crowded with people. We enter each yurt - dead silence, dead town. (ibid.)

This dead town has a real geographical location - Torgai. From the underlying subtext comes Goloshekin, one of the initiators of collectivisation in Kazakhstan, a process that led to the Great Famine. The author uses Goloshekin's name as a coordinate and a framework to the time period. The main street of the dead town is named after Goloshekin to symbolise the cynicism of proprietors and to be on show as the landmark of legal evil. As a result of the political violence against the rural population, the Great Famine lasted from 1931 to 1933 all over the Soviet Union. During the Great Famine the Kazakh people, however, suffered more than any other. Niccolo Pianciola (2001) states that "Kazakhstan had the earliest and most destructive consequences and experience. This ethnicity suffered from land reforms". Recent data shows that the Great Famine 
of 1931-1933 killed 1,450,000 people, which was about $38 \%$ of the population. This is the highest rate among all the Soviet Republics (Pianciola 2004: 137).

\section{CONCLUSION}

Evaluative rereading of the text material and analytical facts shows that Musrepov was true to himself in his works even during the period of total terror. The writer's works demonstrate that he did not give up on his beliefs; he lived by his own principles and followed his own moral values. Research principles of phenomenological historicism indicate the importance of the personal worldview of the author, and this contributes to the originality of the works.

Censors suspected that the author used an undertone or so-called Aesopian language in his works that was sometimes referred to as 'a middle finger in the pocket'. Musrepov appealed to readers' co-authorship, which has such required characteristics as reading between the lines, the ability to find and understand a hidden undertone and interior meaning in the writing. A search for 'second meanings' in the text and their interpretation was an indispensable and necessary attribute of readers' creativity when reading Musrepov's works.

To summarise the idea, it may be said that the fate of most writings by Gabit Musrepov proves one of Mikhail Bakhtin's assumptions: "In the process of posthumous 'life', the works are enriched with new meanings, the writings are developing and reach a new level" (Bakhtin 1986: 350). The bitter historical truth enters into a dialogue with the official state-approved concept of the events crucial to Kazakhs, and is expressed in literary works as a discussion between different worldviews. The tragic scenes from the life of the 'buried aul' are the evidence of forced 'selection': those who survive will be obedient and patient. In this scope, the dialogs and characters of the mentioned works by Musrepov reach up to the level of eternal symbols of worldwide grief and evil.

The Ethnographic Tale, which shows the Kazakh way of life, traditional culture, and aesthetics, becomes a work that shows the true tragedy of the Kazakhs in the 1930s: collectivisation, Stalinist purges, and the dramatic break of people from their previous lives. Grotesque descriptions and undertones in Glow and numerous details of life under Stalin point out the cruel and totalitarian system and dispel the myth of a promising future. The essay titled Why Are the Backs of Their Heads Itching? was considered as politically destructive, showing the Soviet government from its negative side; however, it appeals to the readers' feelings, making them regret the lost cultural values and traditions.

As a highly educated person, Musrepov was the first to see the implacable cruel nature of a system that destroyed the traditional way of life of the Kazakh 
people. The artistic integrity of the three abovementioned works is an epitaph for the destroyed Kazakh traditional culture, showing the hidden life of a suppressed community.

A person of great erudition and sharpened consciousness, Musrepov grasped earlier than others the merciless brutal character of the destruction of Kazakhs' old lifestyle. All the three works show an artistic integrity that is an epitaph to the destruction of Kazakh traditional culture. The integrity is determined by the genre's form, composition similarities, and narrative forms. 'Transparent' topics as intertextual clamps 'cement' the historical chronicle into an integral work of art. Musrepov's artistic space is wide: the cosmic world, the earth world, real and imaginative worlds, the world as a whole universe concurs with the nomadic assumption that the aul is a universal cosmic and life space.

Spatial and temporal concreteness is typical for the works under analysis. The artistic space in which Musrepov works is many-sided: the worlds of the cosmos, the earth, and space - both visible and imaginable - include all the worlds of living beings and draw on imagination about the aul as a universe for the nomad in unity with cosmic and existential spaces. The time of narration is the concrete tragic period of collectivisation with the merciless demolition of the universe, the way of life of the steppe. The organising centre in the minor existence-world is the yurt, widely exploited by the author. The yurt symbolises the motif of the destroyed house (world, existence) of the nomad, but also an irreversibility of violence experienced by the nation. The author connects with great tact ethnographic precision with the moral truth: in the subtext an unhealed national tragedy is shown. In the 1930s, mass literature advocated the idea of collectivisation, protecting 'common life' principles, but Musrepov, contrary to that, depicts the disastrous processes of communalisation of peasants into collective farms. Those contradictions between peasants and the state are revealed throughout the country, and in particular in the region of Kos Shalkar. According to witnesses of that period, when people betrayed friends for personal well-being, Musrepov lived in dignity, loved, wrote his works, and showed fortitude, despite the restricting measures of censorship on writers' works. The talented writer experienced periods of the Red Terror persecution, oblivion, and assault, very often escaping only by chance. He said all he wanted to say and wrote all he intended to write; he did not take part in 'the great conspiracy of silence', and his name and literary heritage are preserved in historical records. 


\section{NOTES}

1 Cited in http://analizators.ru/articlematerial5, last accessed on January 28, 2016.

${ }^{2}$ It is believed that the following methods were employed to get around censorship: allegory (Aesopian language), samizdat (self-publishing), tamizdat (publishing abroad), and other ways. About getting around the censorship limits see: http://analizators.ru/ articlematerial20, last accessed on January 28, 2016.

3 The list of the high awards and titles of the writer is impressive: academician of the Academy of Sciences of the KazSSR (1985), people's writer of the KazSSR (1984), laureate of the Ch. Valikhanov premium for the collection of the literary-critical and publicist works, titled The Duty of an Artist (1977), Chairman of the Supreme Council of Kazakhstan (1974-1975), Hero of Socialist Labour (1974). For the collection of stories titled The Image That I Failed to Meet (1966) he was awarded the State Premium of the Kazakh SSR in 1968 and in 1970 he got the Abay State Premium of the Kazakh SSR for the collection of stories and novels titled Once and for All Life. He was awarded the Order of Lenin three times and he also received other orders and medals.

${ }^{4}$ In 1928 G. Musrepov was the chief editor, and in 1931 head of the Kazgoslitizdat (Kazakh State Publishing House), in 1934 editor of the newspapers Kazakh Culture and Socialist Kazakhstan. In 1934-1935 he was head of political enlightenment work at the Central Committee of the Communist Party of the Kazakh SSR, and in 1936-1937 chairman of arts issues at the Council of People's Commissars of the Kazakh SSR. His biography stated that from 1938 to 1955 Musrepov was a freelance writer. In 1958 he was elected secretary of the Council of Writers of the USSR, and a member of the State Committee of the USSR on Lenin and State Premiums in the Sphere of Literature, Arts, and Architecture (see: Ayagan 2006: 67-67; Ayagan 2004: 648-650; Chernysheva \& Saginaeva 1994: 5-7; Narymbetov 1994: 7-11).

5 See: Musrepov Gabit Makhmudovich (http://el.kz/m/articles/view/content-13417, last accessed on February 26, 2016).

6 This is a reference to Fyodor Dostoyevsky who in his letter to Valikhanov on December 14, 1856, described a similar mission: "to serve his motherland by being an enlightened example to Russians" (Dostoyevsky 1985: 104).

7 Gerold Belger (b. 1934), a contemporary Kazakh writer, interpreter, publicist, author of 53 books, and over 1800 publications in various languages. He has translated twenty works from German into Russian, and over 200 works from Kazakh into Russian.

8 Musrepov's position was recorded in the protocol of the meeting of the party organisation under the Writers' Alliance of Kazakhstan, dated October 8, 1937, when the decision on the expulsion of $\mathrm{B}$. Mailin from the ranks of the communist party was made. It was noted that "comrade Musrepov G., being a member of the Writers' Alliance and head of the cultural enlightenment department of the Central Committee of the Communist Party, made a speech at the party meeting of the Writers' Alliance in July 1937, to openly defend the enemy of the people, B. Mailin; moreover, he suspended the release of a newspaper issue (not being its editor) with the article denouncing Mailin as a nationalist, and re-wrote the article in favour of Mailin" (Beiskulov 2008: 227). At the party meeting on October 8, 1937, when again the issue of Mailin was motioned, 
"comrade Musrepov made a statement and openly defended the enemy Mailin; exploiting his position, he took responsibility in a courageous manner, declaring that he, Musrepov, knew Mailin quite well [---] and that he trusted Mailin politically and was ready to warrant him, and therefore, he, Musrepov, defended and would defend him from the people who accused Mailin of nationalism" (ibid.: 228). "There are many other facts proving the connection between Musrepov and Mailin and other people's enemies, such as Seifullin, Lebedenko [---] (our information is that they had been arrested by that time). Pass the case of comrade Musrepov to consider his belonging to the party organisation of the Central Committee of the Communist Party of Kazakhstan" (ibid.: 229). (The document style is kept without changes - authors.)

9 Literary critic Per-Arne Bodin asserts that kotlovan (the foundation pit) is another comprehensive metaphor in Platonov's novel with the same title. As Per-Arne Bodin has mentioned, one would think that the foundation pit fully fits in the context of the novel. But in Platonov's novel the foundation pit becomes a tomb, not the first element of constructing an apartment building for the proletariat. In the novel it becomes a symbol of the region beyond the grave and heroes; indeed, it interprets the foundation pit as a grave (see Bodin 1994: 170-174).

\section{REFERENCES}

Ayagan, Burkut (ed.) 2004. Musrepov, Gabit. In: Qazaqstan: Ulttūq entsiklopediiasū. [Kazakhstan: The National Encyclopaedia.] T. 6. Almaty: Qazaq entsiklopediiasy, pp. $648-650$.

Ayagan, Burkut (ed.) 2006. Musrepov, Gabit. In: Kazakhstan: Natsional'naia entsiklopediia. [Kazakhstan: The National Encyclopaedia.] T. 4. Almaty: Qazaq entsiklopediiasy, pp. 65-67. Available at http://www.madenimura.kz/ru/culture-legacy/books/book/ kazahstan-nacionalnaa-enciklopedia-4-tom?category=all\&page=66, last accessed on February 2, 2016.

Bakhtin, Mikhail 1986. Estetika slovesnogo tvorchestva. [The Aesthetics of the Verbal Art.] Moskva: Iskusstvo.

Beiskulov, Toktar 2008. Ghabit Müsirepov: Beimbet zhau bolsa, men de zhaumyn. [Gabit Musrepov: If Beimbet is Enemy, I Am Enemy Too.] In: T. Beiisqulov. Bes tomdūq zhinaghū. [Five-Volume Collection of Works.] T. 3. Almaty: Tolganai, pp. 219-244.

Belger, Gerold 2002. Musrepov zhdet svoego perevodchika. [Musrepov Waits for His Translator.] Kazakhstanskaia Pravda, June 22, No. 137-138 (23786-23787).

Bodin, Per-Arne 1994. Zagrobnoe tsarstvo i Vavilonskaia bashnia: O povesti Platonova "Kotlovan". [The Kingdom beyond the Grave and the Babylon Tower: On the Story "Kotlovan" by Platonov.] In: I. Avramets (comp.) Klassitsizm i modernizm: Sbornik statei. Tartu: Tartu Ülikooli Kirjastus, pp. 168-183. Available at http:// www.ruthenia.ru/reprint/klassicizm/bodin.pdf, last accessed on February 1, 2016.

Chernysheva, N. \& Saginaeva, L. (eds.) 1994. Musrepov, Gabit: kratkie svedeniia o zhizni i tvorchestve. In: Bibliograficheskii ukazatel' literatury. [Bibliographical Index of Literature.] Almaty: Zhazyshy, pp. 5-7.

Derrida, Jacques 1985. Letter to a Japanese Friend. In: D. Wood \& R. Bernasconi (eds.) Derrida and Difference. Warwick: Parousia Press, pp. 1-5. 
Dostoyevsky, Fyodor 1985. Polnoe sobranie sochinenii. [Complete Collection of Works.] Vol. 1. Leningrad: Nauka.

Gribanova, Elena 2003. Posleslovie k "Pis'mu piati". [Postscript to the "Letter of the Five".] Kazakhstanskaia Pravda, May 16, No. 141-142 (24081-24082). Available at http://www.nomad.su/?a=15-200305170026, last accessed on February 2, 2016.

Huizinga 1992 = Kheizinga, Iokhan. Homo Ludens. V teni zavtrashnego dnia. [Homo Ludens. In the Shadow of Tomorrow.] Moskva: Progress. Available at http://tlf. narod.ru/school/Homo_Ludens/text.htm, last accessed on February 2, 2016.

Kaiyrbekov, Gafu 1990. Eltinzhal: Povest'-esse. [Eltinzhal: Story-Essay.] Almaty: Öner. Musrepov, Gabit 1962. Iz staroi tetradi. [From an Old Notebook.] Druzhba Narodov, No. 11 , pp. $73-80$.

Musrepov, Gabit 1977. Etnografski razkaz. [An Ethnographic Tale.] In: Slava Nikolova (comp. \& trans.) Shchastliviiat klas: Razkazi za s"vetskoto selo. [Happy Class: Stories on the Soviet Village.] Sofia: BZNC, pp. 94-108.

Musrepov, Gabit 1980a. Tangdamaly shygharmalar: Üshtomdyq. [Selected Works: In Three Volumes.] Tom 1. Almaty: Zhazyshy.

Musrepov, Gabit 1980b. Tangdamaly shygharmalar: Üshtomdyq. [Selected Works: In Three Volumes.] Tom 2. Almaty: Zhazyshy.

Musrepov, Gabit 1982. Izbrannye proizvedeniia v dvukh tomakh. [Selected Works in Two Volumes]. Tom 2. Almaty: Khudozhestvennaia literatura.

Musrepov, Gabit 1997. Kündelik. [Diary.] Moskva \& Almaty: Ana tili.

Musrepov, Gabit 2013. An Ethnographic Tale. In: Rafis Abazov (ed.) The Stories of the Great Steppe: The Anthology of Modern Kazakh Literature. Trans. by Sergio Levchin \& Ilya Bernshtein. San Diego, CA: Cognella Academic Publishing, pp. 11-18.

Narymbetov, K. E. (ed.) 1994. Musrepov, Gabit: Ömiri men engbegine qysqasha maghlumat. [Gabit Musrepov: Short Information about Biography and Works.] In: Bibliografiialyq körsetkish. [Bibliographical Index.] Almaty: Zhazyshy.

Pianciola, Niccolò 2004. Famine in the Steppe. Cahiers du Monde russe, Vol. 45/1, No. 2, pp. 137-192. Available at http://monderusse.revues.org/2623?file=1, last accessed on February 2, 2016.

Shimyrbaeva, Galia 2002. On ne izmenil druzhbe dazhe pod strakhom smerti. [He Did Not Betray Friendship Even Under the Fear of Death.] Kazakhstanskaia Pravda, June 14, No. 131, p. 4.

\section{INTERNET SOURCES}

Obkhod tsenzurnykh ogranichenii. [Avoiding the Censorship Limits.] Available at http:// analizators.ru/articlematerial20, last accessed on February 1, 2016.

Sozdanie Glavlita. [The Establishment of Glavlit.] Available at http://analizators.ru/ articlematerial5, last accessed on February 1, 2016. 